\title{
Could Lipoprotein Lipase Play a Role in Alzheimer's Disease?
}

\author{
Jean-François Blain ${ }^{1}$ and Judes Poirier*,1,2 \\ ${ }^{1}$ Douglas Hospital Research Center and ${ }^{2}$ McGill Center for Studies in Aging, 6825 \\ LaSalle Blvd, Verdun, Quebec, Canada, H4H 1R3 \\ E-mail: jean-francois.blain@mail.mcgill.ca; judes.poirier@mcgill.ca
}

Received June 4, 2004; Revised July 8, 2004; Accepted July 12, 2004; Published July 20, 2004

This paper reviews recent literature on the role of lipoprotein lipase in the central nervous system with a focus on its recently described role in synaptic remodeling. This novel role could have implication for Alzheimer's disease treatment.

KEYWORDS: lipoprotein lipase (LPL), cholesterol, lipids, Alzheimer's disease (AD), synaptic remodeling, proteoglycans, amyloid

DOMAINS: aging, biochemistry, cell biology, neuroscience, neurology, metabolism

In 2000, there were an estimated 18 million persons worldwide with dementia, with more than half suffering from Alzheimer's disease (AD). Considering the aging of the population and a projected increase in survival, this number is predicted to reach 37 million by 2025.

It is now well established that the causes for familial AD (10-15\% of all AD cases) are associated with an increased production of a peptide called beta-amyloid (A $\beta)$, resulting from mutations in the genes coding for either the amyloid precursor protein (APP)[1,2,3], presenilin-1[4,5], or presenilin-2[6]. It was also shown that a polymorphism in the apolipoprotein (apo) E gene, giving rise to an isoform called apoE4, is strongly associated to both familial and sporadic (common form) AD. ApoE4, a common transporter of lipid in the brain and in periphery, is now recognized as the major risk factor for the development of late-onset sporadic and familial $\mathrm{AD}[7,8,9]$.

ApoE in the brain regulates the transport and distribution of cholesterol and lipids from the astrocytes, where they are stored, to neurons that are in need of these constituents for membrane synthesis and reinnervation purposes. Several studies reported close association between cholesterol metabolism, A $\beta$ generation, and amyloid deposition[10,11,12,13,14]. Thus, it is not surprising to see cholesterol homeostasis become a major target for potential therapy in $\mathrm{AD}[15,16,17]$.

In a recent report[18], we described a potentially new function for lipoprotein lipase (LPL) during synaptic remodeling in the mouse adult brain. In periphery, LPL is known to hydrolyze triglycerides, but also helps to regulate the internalization of lipoproteins in different cell types. This protein is also interesting from an $\mathrm{AD}$ point of view as it interacts with brain lipoproteins and binds to their receptors, modulating cholesterol homeostasis in neuronal cells.

LPL deficiency has been linked to specific neurological disorders, supporting the notion of a central role in brain functions[19,20]. While being expressed throughout the brain, LPL was shown to have its 
highest levels in the hippocampus[21,22,23]. Its activity increased during brain development with a peak at 10 days postnatal, followed by a progressive decline in adulthood[21]. To be catalytically active, LPL requires the presence of significant amounts of apoCII, a cofactor relatively absent from the brain parenchyma[24,25,26,27]. On the other hand, it was shown to modulate, in a cofactor-independent manner, the binding and internalization of lipoprotein particles[28,29]. LPL is involved in the transfer of vitamin $E$ to tissues[30] and it mediates the internalization of cholesteryl ester-rich HDL particles[31,32,33]. These particles exhibit properties similar to the HDL particles found in the CSF and the brain[34,35]. LPL is known to bind to the different members of the low-density lipoprotein receptor (LDLR) family[36,37,38,39,40], but its major binding site is on the heparan sulfate proteoglycans (HSPGs) found at the surface of the plasma membrane[41,42,43]. In the peripheral sciatic nerve crush, an increase in LPL was observed and it was proposed to act as a recycling system for the lipid breakdown products[44]. It was also shown to induce neurite outgrowth of sympathetic neurons through LRPmediated endocytosis[45]. In relation to AD, LPL was found to accumulate in senile plaques[46] and a specific genetic polymorphism was shown to be associated with the disease incidence in clinically diagnosed AD subjects[47]. Recently, three independent studies failed to replicate the reported association in different cohorts of subjects[48,49,50].

Using a mouse model of hippocampal deafferentation that mimics some of the pathological features found in AD, we showed that LPL mRNA and protein levels were upregulated during the degenerative phase, with a peak at 2 days postlesion. Levels were back to basal levels shortly after the reinnervation phase. This led us to propose a role for LPL in the recycling of the lipids and cholesterol released from the degenerating terminals toward the reinnervating neurons. Interestingly, Paradis et al. also showed increased LPL expression early after brain damage using a focal ischemia model[23] as well as an increase in neurite outgrowth of LPL-transfected cells exposed to VLDL[51].

As LPL is known to bind to several members of the LDL receptor family, we examined the expressions of LPL target protein as a function of deafferentation and reinnervation in the lesioned animals. In addition to the classic LDL receptor, we also examined the LRP and apoER2 expression as well as that of syndecan-4, a glia-specific HSPG. LRP and apoER2 levels are not affected by the deafferentation process, whereas the LDLR expression is somewhat downregulated 6 days after the lesion. On the other hand, the proteoglycan syndecan-4 was shown to be upregulated at 2 days postlesion in astrocytes, coinciding with the peak expression of LPL in the deafferented hippocampus. It is thus tempting to propose that LPL-rich lipoprotein complexes present in the extracellular space interact with the cell-surface syndecan-4 on astrocytes to permit the functional transfer of cholesterol from storage organelles toward the cell surface where lipoprotein complexes are anchored to the membrane. ApoE, whose expression level peaks a few days later, would subsequently be added to the lipoprotein structure. The cholesterol-rich complex could then diffuse toward nearby neuronal cells expressing apoE receptors belonging to the LDLR family. The complex would then be internalized and the cholesterol released intracellularly for membrane assembly purposes.

To summarize, we reported the first evidence that LPL is actively involved in synaptic remodeling in the adult CNS following deafferentation and that glial syndecan-4 is an integral part of this process. The members of the syndecan family as well as LPL were shown to be present in senile plaques and neurofibrillary tangles in the AD brain[52,53]. The recent development of experimental therapies based on the binding properties of $A \beta$ to the glycosaminoglycan side chains of HSPGs such as syndecan$4[54,55]$ is consistent with the role we propose for it in remodeling.

\section{ACKNOWLEDGMENTS}

The authors would like to acknowledge the financial support of the Alzheimer's Society of Canada and the Canadian Institute of Health Research. 


\section{REFERENCES}

1. $\quad$ Citron, M., Oltersdorf, T., Haass, C., McConlogue, L., Hung, A.Y., Seubert, P., Vigo-Pelfrey, C., Lieberburg, I., and Selkoe, D.J. (1992) Mutation of the beta-amyloid precursor protein in familial Alzheimer's disease increases betaprotein production. Nature 360, 672-674.

2. Haass, C., Lemere, C.A., Capell, A., Citron, M., Seubert, P., Schenk, D., Lannfelt, L., and Selkoe, D.J. (1995) The Swedish mutation causes early-onset Alzheimer's disease by beta-secretase cleavage within the secretory pathway. Nat. Med. 1, 1291-1296.

3. Haass, C., Hung, A.Y., Selkoe, D.J., and Teplow, D.B. (1994) Mutations associated with a locus for familial Alzheimer's disease result in alternative processing of amyloid beta-protein precursor. J. Biol. Chem. 269, 1774117748.

4. $\quad$ St George-Hyslop, P., Haines, J., Rogaev, E., Mortilla, M., Vaula, G., Pericak-Vance, M., Foncin, J.F., Montesi, M., et al. (1992) Genetic evidence for a novel familial Alzheimer's disease locus on chromosome 14. Nat. Genet. 2, 330-334.

5. Sherrington, R., Rogaev, E.I., Liang, Y., Rogaeva, E.A., Levesque, G., Ikeda, M., Chi, H., Lin, C., et al. (1995) Cloning of a gene bearing missense mutations in early-onset familial Alzheimer's disease. Nature 375, 754-760.

6. Rogaev, E.I., Sherrington, R., Rogaeva, E.A., Levesque, G., Ikeda, M., Liang, Y., Chi, H., Lin, C., et al. (1995) Familial Alzheimer's disease in kindreds with missense mutations in a gene on chromosome 1 related to the Alzheimer's disease type 3 gene. Nature 376, 775-778.

7. Poirier, J., Davignon, J., Bouthillier, D., Kogan, S., Bertrand, P., and Gauthier, S. (1993) Apolipoprotein E polymorphism and Alzheimer's disease. Lancet 342, 697-699.

8. $\quad$ Strittmatter, W.J., Saunders, A.M., Schmechel, D., Pericak-Vance, M., Enghild, J., Salvesen, G.S., and Roses, A.D. (1993) Apolipoprotein E: high-avidity binding to beta-amyloid and increased frequency of type 4 allele in late-onset familial Alzheimer disease. Proc. Natl. Acad. Sci. U. S. A. 90, 1977-1981.

9. $\quad$ Corder, E.H., Saunders, A.M., Strittmatter, W.J., Schmechel, D.E., Gaskell, P.C., Small, G.W., Roses, A.D., Haines, J.L., and Pericak-Vance, M.A. (1993) Gene dose of apolipoprotein E type 4 allele and the risk of Alzheimer's disease in late onset families. Science 261, 921-923.

10. Sparks, D.L., Scheff, S.W., Hunsaker, J.C., III, Liu, H., Landers, T., and Gross, D.R. (1994) Induction of Alzheimerlike beta-amyloid immunoreactivity in the brains of rabbits with dietary cholesterol. Exp. Neurol. 126, 88-94.

11. Howland, D.S., Trusko, S.P., Savage, M.J., Reaume, A.G., Lang, D.M., Hirsch, J.D., Maeda, N., Siman, R., et al. (1998) Modulation of secreted beta-amyloid precursor protein and amyloid beta-peptide in brain by cholesterol. $J$. Biol. Chem. 273, 16576-16582.

12. Refolo, L.M., Pappolla, M.A., Malester, B., LaFrancois, J., Bryant-Thomas, T., Wang, R., Tint, G.S., Sambamurti, K., and Duff, K. (2000) Hypercholesterolemia accelerates the Alzheimer's amyloid pathology in a transgenic mouse model. Neurobiol. Dis. 7, 321-331.

13. Puglielli, L., Konopka, G., Pack-Chung, E., Ingano, L.A., Berezovska, O., Hyman, B.T., Chang, T.Y., Tanzi, R.E., and Kovacs, D.M. (2001) Acyl-coenzyme A: cholesterol acyltransferase modulates the generation of the amyloid beta-peptide. Nat. Cell Biol. 3, 905-912.

14. Ehehalt, R., Keller, P., Haass, C., Thiele, C., and Simons, K. (2003) Amyloidogenic processing of the Alzheimer betaamyloid precursor protein depends on lipid rafts. J. Cell Biol. 160, 113-123.

15. Jick, H., Zornberg, G.L., Jick, S.S., Seshadri, S., and Drachman, D.A. (2000) Statins and the risk of dementia. Lancet 356, 1627-1631.

16. Wolozin, B., Kellman, W., Ruosseau, P., Celesia, G.G., and Siegel, G. (2000) Decreased prevalence of Alzheimer disease associated with 3-hydroxy-3-methyglutaryl coenzyme A reductase inhibitors. Arch. Neurol. 57, 1439-1443.

17. Poirier, J. and Panisset, M. (2002) Apolipoprotein E: a novel therapeutic target for the treatment of Alzheimer's disease. In Mapping the Progress of Alzheimer's and Parkinson's Disease. Mizuno, Y., Fisher, A., and Hanin, I., Eds. Kluwer Academic/Plenum Publishers, New York. pp. 39-43.

18. Blain, J.F., Paradis, E., Gaudreault, S.B., Champagne, D., Richard, D., and Poirier, J. (2004) A role for lipoprotein lipase during synaptic remodeling in the adult mouse brain. Neurobiol. Dis. 15, 510-519.

19. Chait, A., Robertson, H.T., and Brunzell, J.D. (1981) Chylomicronemia syndrome in diabetes mellitus. Diabetes Care 4, 343-348.

20. Brunzell, J.D. (1989) Familial lipoprotein lipase deficiency and other causes of chylomicronemia syndrome. In The Metabolic Basis of Inherited Disease. Scriver, C.R., Beaudet, A.L., Sly, W.S., and Valle, D., Eds. McGraw-Hill, New York. pp. 1165-1180.

21. Ben-Zeev, O., Doolittle, M.H., Singh, N., and Schotz, M.C. (1990) Synthesis and regulation of lipoprotein lipase in the hippocampus. J. Lipid Res. 31, 1307-1313.

22. Nunez, M., Peinado-Onsurbe, J., Vilaro, S., and Llobera, M. (1995) Lipoprotein lipase activity in developing rat brain areas. Biol. Neonate 68, 119-127.

23. Paradis, E., Clavel, S., Julien, P., Murthy, M.R., de Bilbao, F., Arsenijevic, D., Giannakopoulos, P., Vallet, P., and Richard, D. (2004) Lipoprotein lipase and endothelial lipase expression in mouse brain: regional distribution and selective induction following kainic acid-induced lesion and focal cerebral ischemia. Neurobiol. Dis. 15, 312-325. 
24. Zannis, V.I., Cole, F.S., Jackson, C.L., Kurnit, D.M., and Karathanasis, S.K. (1985) Distribution of apolipoprotein AI, C-II, C-III, and E mRNA in fetal human tissues. Time-dependent induction of apolipoprotein E mRNA by cultures of human monocyte-macrophages. Biochemistry 24, 4450-4455.

25. Datta, S., Li, W.H., Ghosh, I., Luo, C.C., and Chan, L. (1987) Structure and expression of dog apolipoprotein C-II and C-III mRNAs. Implications for the evolution and functional constraints of apolipoprotein structure. J. Biol. Chem. 262, 10588-10593.

26. Hoffer, M.J., van Eck, M.M., Havekes, L.M., Hofker, M.H., and Frants, R.R. (1993) Structure and expression of the mouse apolipoprotein C2 gene. Genomics 17, 45-51.

27. Lenich, C., Brecher, P., Makrides, S., Chobanian, A., and Zannis, V.I. (1988) Apolipoprotein gene expression in the rabbit: abundance, size, and distribution of apolipoprotein mRNA species in different tissues. J. Lipid Res. 29, 755764.

28. Merkel, M., Heeren, J., Dudeck, W., Rinninger, F., Radner, H., Breslow, J.L., Goldberg, I.J., Zechner, R., and Greten, H. (2002) Inactive lipoprotein lipase (LPL) alone increases selective cholesterol ester uptake in vivo, whereas in the presence of active LPL it also increases triglyceride hydrolysis and whole particle lipoprotein uptake. J. Biol. Chem. 277, 7405-7411.

29. Merkel, M., Kako, Y., Radner, H., Cho, I.S., Ramasamy, R., Brunzell, J.D., Goldberg, I.J., and Breslow, J.L. (1998) Catalytically inactive lipoprotein lipase expression in muscle of transgenic mice increases very low density lipoprotein uptake: direct evidence that lipoprotein lipase bridging occurs in vivo. Proc. Natl. Acad. Sci. U. S. A. 95, 1384113846.

30. Traber, M.G., Olivecrona, T., and Kayden, H.J. (1985) Bovine milk lipoprotein lipase transfers tocopherol to human fibroblasts during triglyceride hydrolysis in vitro. J. Clin. Invest. 75, 1729-1734.

31. Schorsch, F., Malle, E., and Sattler, W. (1997) Selective uptake of high density lipoprotein-associated cholesterylesters by differentiated Ob1771 adipocytes is modulated by endogenous and exogenous lipoprotein lipase. FEBS Lett. 414, 507-513.

32. Panzenboeck, U., Wintersberger, A., Levak-Frank, S., Zimmermann, R., Zechner, R., Kostner, G.M., Malle, E., and Sattler, W. (1997) Implications of endogenous and exogenous lipoprotein lipase for the selective uptake of HDL3associated cholesteryl esters by mouse peritoneal macrophages. J. Lipid Res. 38, 239-253.

33. Rinninger, F., Kaiser, T., Mann, W.A., Meyer, N., Greten, H., and Beisiegel, U. (1998) Lipoprotein lipase mediates an increase in the selective uptake of high density lipoprotein-associated cholesteryl esters by hepatic cells in culture. $J$. Lipid Res. 39, 1335-1348.

34. LaDu, M.J., Reardon, C., Van Eldik, L., Fagan, A.M., Bu, G., Holtzman, D., and Getz, G.S. (2000) Lipoproteins in the central nervous system. Ann. N. Y. Acad. Sci. 903, 167-175.

35. Fagan, A.M., Holtzman, D.M., Munson, G., Mathur, T., Schneider, D., Chang, L.K., Getz, G.S., Reardon, C.A., et al. (1999) Unique lipoproteins secreted by primary astrocytes from wild type, apoE (-/-), and human apoE transgenic mice. J. Biol. Chem. 274, 30001-30007.

36. Beisiegel, U., Weber, W., and Bengtsson-Olivecrona, G. (1991) Lipoprotein lipase enhances the binding of chylomicrons to low density lipoprotein receptor-related protein. Proc. Natl. Acad. Sci. U. S. A. 88, 8342-8346.

37. Medh, J.D., Bowen, S.L., Fry, G.L., Ruben, S., Andracki, M., Inoue, I., Lalouel, J.M., Strickland, D.K., and Chappell, D.A. (1996) Lipoprotein lipase binds to low density lipoprotein receptors and induces receptor-mediated catabolism of very low density lipoproteins in vitro. J. Biol. Chem. 271, 17073-17080.

38. Takahashi, S., Suzuki, J., Kohno, M., Oida, K., Tamai, T., Miyabo, S., Yamamoto, T., and Nakai, T. (1995) Enhancement of the binding of triglyceride-rich lipoproteins to the very low density lipoprotein receptor by apolipoprotein E and lipoprotein lipase. J. Biol. Chem. 270, 15747-15754.

39. Kounnas, M.Z., Chappell, D.A., Strickland, D.K., and Argraves, W.S. (1993) Glycoprotein 330, a member of the low density lipoprotein receptor family, binds lipoprotein lipase in vitro. J. Biol. Chem. 268, 14176-14181.

40. Tacken, P.J., de Beer, F., van Vark, L.C., Havekes, L.M., Hofker, M.H., and van Dijk, K.W. (2000) Very-low-density lipoprotein binding to the apolipoprotein E receptor 2 is enhanced by liopoprotein lipase, and does not require apolipoprotein E. Biochem. J. 347, 357-361.

41. Eisenberg, S., Sehayek, E., Olivecrona, T., and Vlodavsky, I. (1992) Lipoprotein lipase enhances binding of lipoproteins to heparan sulfate on cell surfaces and extracellular matrix. J. Clin. Invest. 90, 2013-2021.

42. Mulder, M., Lombardi, P., Jansen, H., van Berkel, T.J., Frants, R.R., and Havekes, L.M. (1992) Heparan sulphate proteoglycans are involved in the lipoprotein lipase-mediated enhancement of the cellular binding of very low density and low density lipoproteins. Biochem. Biophys. Res. Commun. 185, 582-587.

43. Williams, K.J., Fless, G.M., Petrie, K.A., Snyder, M.L., Brocia, R.W., and Swenson, T.L. (1992) Mechanisms by which lipoprotein lipase alters cellular metabolism of lipoprotein(a), low density lipoprotein, and nascent lipoproteins. Roles for low density lipoprotein receptors and heparan sulfate proteoglycans. J. Biol. Chem. 267, 13284-13292.

44. Huey, P.U., Waugh, K.C., Etienne, J., and Eckel, R.H. (2002) Lipoprotein lipase is expressed in rat sciatic nerve and regulated in response to crush injury. J. Lipid Res. 43, 19-25.

45. Postuma, R.B., Martins, R.N., Cappai, R., Beyreuther, K., Masters, C.L., Strickland, D.K., Mok, S.S., and Small, D.H. (1998) Effects of the amyloid protein precursor of Alzheimer's disease and other ligands of the LDL receptor-related protein on neurite outgrowth from sympathetic neurons in culture. FEBS Lett. 428, 13-16. 
46. Rebeck, G.W., Harr, S.D., Strickland, D.K., and Hyman, B.T. (1995) Multiple, diverse senile plaque-associated proteins are ligands of an apolipoprotein E receptor, the alpha 2-macroglobulin receptor/low-density-lipoprotein receptor-related protein. Ann. Neurol. 37, 211-217.

47. Baum, L., Chen, L., Masliah, E., Chan, Y.S., Ng, H.K., and Pang, C.P. (1999) Lipoprotein lipase mutations and Alzheimer's disease. Am. J. Med. Genet. 88, 136-139.

48. Martin-Rehrmann, M.D., Cho, H.S., and Rebeck, G.W. (2002) Lack of association of two lipoprotein lipase polymorphisms with Alzheimer's disease. Neurosci. Lett. 328, 109-112.

49. Fidani, L., Compton, D., Hardy, J., Petersen, R.C., Tangalos, E., Mirtsou, V., Goulas, A., and De Vrieze, F.W. (2002) No association between the lipoprotein lipase S447X polymorphism and Alzheimer's disease. Neurosci. Lett. 322, 192-194.

50. Retz, W., Thome, J., Durany, N., Harsanyi, A., Retz-Junginger, P., Kornhuber, J., Riederer, P., and Rosler, M. (2001) Potential genetic markers of sporadic Alzheimer's dementia. Psychiatr. Genet. 11, 115-122.

51. Paradis, E., Julien, P., and Ven Murthy, M.R. (2004) Requirement for enzymatically active lipoprotein lipase in neuronal differentiation: a site-directed mutagenesis study. Brain Res. Dev. Brain Res. 149, $29-37$.

52. Verbeek, M.M., Otte-Holler, I., van den, B.J., van den Heuvel, L.P., David, G., Wesseling, P., and de Waal, R.M. (1999) Agrin is a major heparan sulfate proteoglycan accumulating in Alzheimer's disease brain. Am. J. Pathol. 155, 2115-2125.

53. van Horssen, J., Kleinnijenhuis, J., Maass, C.N., Rensink, A.A., Otte-Holler, I., David, G., van den Heuvel, L.P., Wesseling, P., et al. (2002) Accumulation of heparan sulfate proteoglycans in cerebellar senile plaques. Neurobiol. Aging 23, 537-545.

54. Gervais, F., Chalifour, R., Garceau, D., Kong, X., Laurin, J., Mclaughlin, R., Morissette, C., and Paquette, J. (2001) Glycosaminoglycan mimetics: a therapeutic approach to cerebral amyloid angiopathy. Amyloid 8(Suppl. 1), 28-35.

55. Gervais, F., Morissette, C., and Kong, X. (2003) Proteoglycans and amyloidogenic proteins in peripheral amyloidosis. Curr. Med. Chem. 3, 361-370.

\section{This article should be referenced as follows:}

Blain, J.-F. and Poirier, J. (2004) Could lipoprotein lipase play a role in Alzheimer's disease? TheScientificWorldJOURNAL 4, 531-535.

\section{Handling Editor:}

Martin Gotte, Principal Editor for Cell Biology and Editorial Board Member for Biochemistry — domains of TheScientificWorldJOURNAL. 


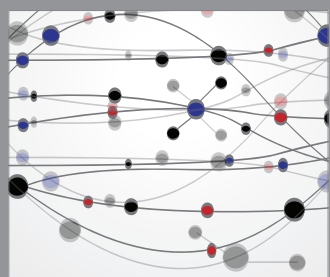

The Scientific World Journal
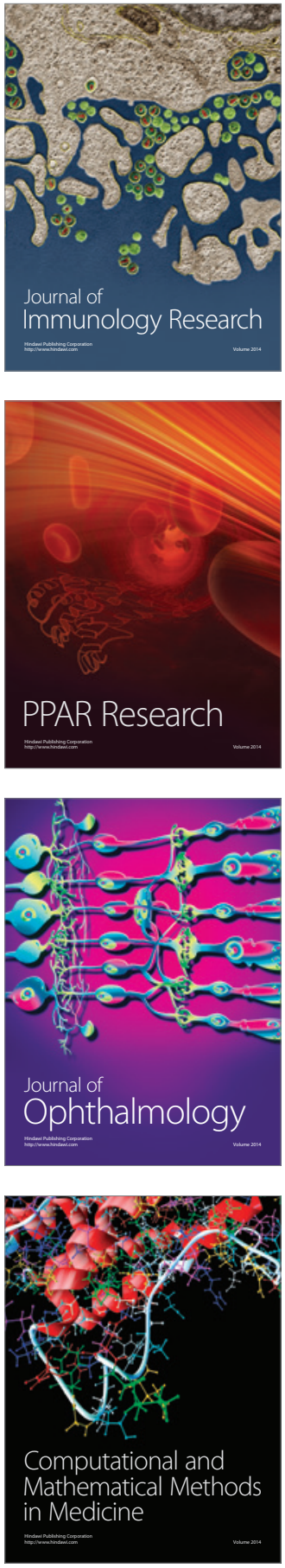

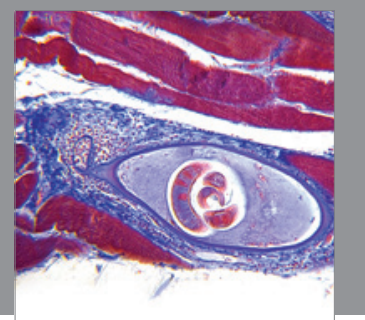

Gastroenterology

Research and Practice
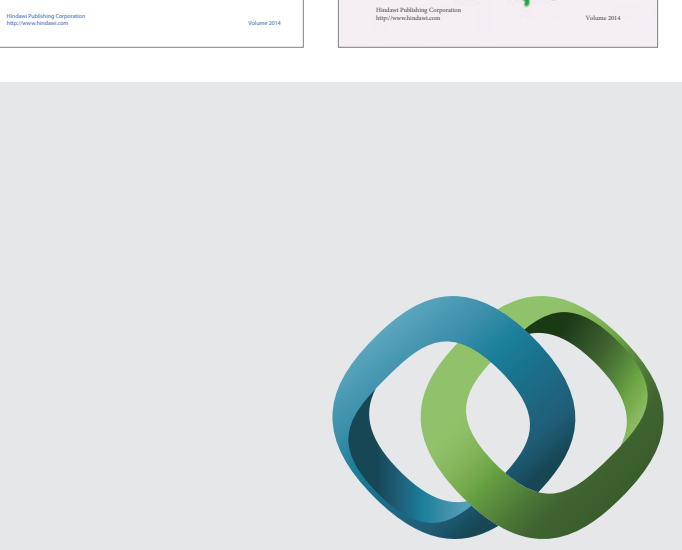

\section{Hindawi}

Submit your manuscripts at

http://www.hindawi.com
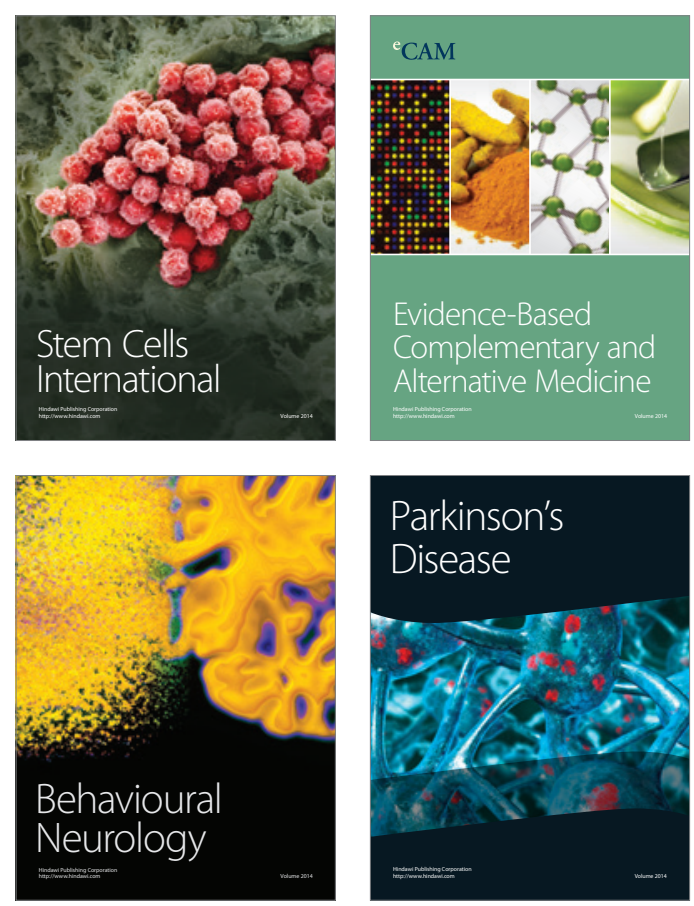

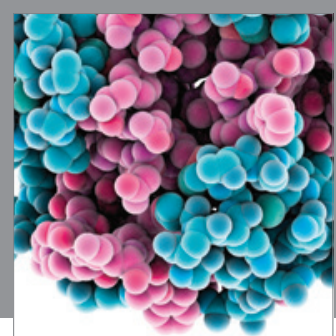

Journal of
Diabetes Research

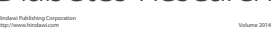



Disease Markers
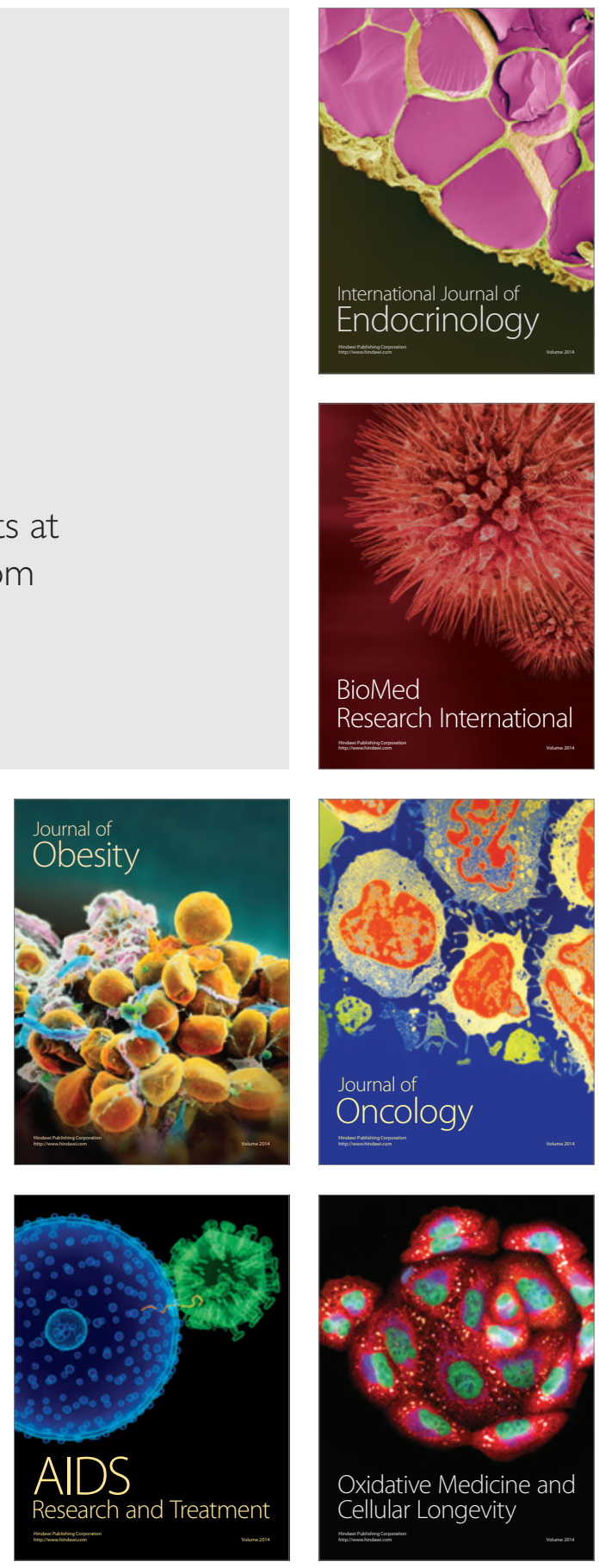